\title{
Physiological quality of citrandarins, Poncirus trifoliata and Sunki mandarin seeds
}

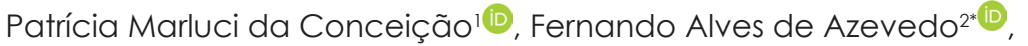 \\ Gerhard Vitor Ecker ${ }^{1}$ (D), Marilia Morelli² (D), Mariangela Cristofani-Yaly² (D) \\ 'Federal University of São Carlos, Araras, Brazil \\ ${ }^{2}$ Sylvio Moreira Citriculture Center, Agronomic Institute, Cordeirópolis, Brazil \\ *Corresponding author, e-mail: fernando@ccsm.br
}

\begin{abstract}
Rangpur lime is the rootstock most used in Brazil, mainly due to its resistance to drought; however, it is susceptible to several diseases, requiring the search for other rootstocks tolerant to factors limiting citrus cultivation. In addition, the Brazilian legislation stipulates that citrus seeds can only be commercialized with at least $50 \%$ germination rate. Thus, the aim of this work was to evaluate the physiological quality of seeds of seven citrus rootstocks. The following citrus fruits were harvested: Poncirus trifoliata, Sunki mandarin and their hybrids citrandarins $(70,106,254,299$ and 310). Fruit mass, diameter and height were measured. Seeds were extracted from fruits, counting the number of normal seeds (not aborted). Seeds were dried up to $20 \%$ water content and stored for 3, 6, 9 and 12 months. The physiological quality of seeds was evaluated before storage (time 0) up to 12 months of storage. The quality of Poncirus trifoliata, Sunki mandarin and citrandarins 70, 106, 254, 299 and 310 seeds was reduced during storage. However, their germination rate remained above $50 \%$, evidencing that seeds of all rootstocks could be marketed until 12 months of storage. The new rootstocks tested have seeds with physiological quality compatible with their parents, in compliance with current legislation.
\end{abstract}

Keywords: germination, emergency, storage, rootstock, citriculture

\section{Introduction}

Brazil is the world's second largest citrus producer, with production of approximately 19.6 million tons, and the world's largest orange producer (17.3 million tonnes), followed by India, Mexico and the United States (FAO, 2018).

Aiming at productive orchards, citrus seedling is the most important input in the formation of an orchard. Its production has had significant evolution in recent decades due to the advancement of technologies that have boosted the sector, which have been developed from partnerships among research and educational institutions, rural extension agencies and producers (Jorge, 2016).

Due to phytosanitary problems that citrus has presented in recent years and the advance of production to new areas, the use of healthy and certified seedlings is an important preventive measure to prevent the occurrence of diseases in Brazilian orchards, such as huanglongbing - HLB (Candidatus Liberibacter spp) (Bassanezi et al., 2011). One of the important steps in the formation of productive orchards is the use of rootstocks with recognized resistance to certain diseases, requiring seeds with sufficient quality and quantity to meet demands (Zucoloto et al., 2011).

Rangpur lime (Citrus limonia Osbeck) is used in most Brazilian citrus orchards, which increases citrus vulnerability to pests and diseases. According to the Agricultural Defense Coordination (unpublished data), 4,546,104 Rangpur lime seedlings were sold in 2018 in the state of São Paulo, representing $34.3 \%$ of the total rootstock seedlings used. The use of Swingle citrumelo [P. trifoliata (L.) Raf $\times$ C. paradise Mcf] in seedling production exceeded Rangpur lime, representing $45 \%$ of the total produced, while Sunki mandarin (C. sunki Hort. ex Tan.) represented $6 \%$, trifoliata (P. trifoliata (L.) Raf) $2.5 \%$ and citrandarins $0.1 \%$.

The expansion of the genetic base related to varieties used as rootstocks, including those able to adapt to abiotic stresses, has decisively contributed to achieve economically higher yields (Brito et al., 2008).

The Sylvio Moreira Citriculture Center of the Agronomic Institute (IAC) has conducted since 1994 a broad genetic breeding program of citrus via directed 
crosses. Among these, new hybrids, such as citrandarins, Citrus sunki x Poncirus trifoliata cv Rubidoux hybrids, were selected because they provide high yield, compatibility with Pêra orange variety and satisfactory drought tolerance when compared to Rangpur lime. They are a new generation of rootstocks, have tolerance to citrus blight, to citrus exocortis viroid, to citrus sudden death (CSD); immunity to citrus tristeza virus and citrus nematode; resistance to Phytophthora gummosis and great tolerance to cold, as well as ability to induce the formation of compact and productive plants (Schinor et al., 2013).

Citrus rootstocks are propagated via seed, so the Ministry of Agriculture, Livestock and Supply (MAPA) established Normative Instruction 48, of September 24, 2013, requiring producers to meet pre-established parameters. Citrus seeds should be analyzed according to Seed Analysis Rules, requiring minimum of $50 \%$ germination for marketing (MAPA, 2018). Thus, the aim of this work was to evaluate the physiological quality of new citrandarin, Poncirus trifoliata and Sunki mandarin seeds.

\section{Material and Methods}

Harvest and plant material

Forty rootstock fruits: $P$. trifoliata, Sunki mandarin (C. sunki) and citrandarins (70, 106, 254, 299 and 310) were harvested from clonal garden plants belonging to the Sylvio Moreira Citriculture Center of the Agronomic Institute (IAC), in Cordeirópolis, state of São Paulo, Brazil. After harvest, fruits were separated into four replicates with 10 fruits each to perform evaluations.

Fruit Analysis

Mass

Mass was determined by weighing on a digital scale with maximum capacity of 15 kilos, obtaining the total sample value and subsequently the average mass of each fruit.

\section{Fruit Diameter and Height}

Diameter was measured using a tape graduated in centimeters, where fruits were placed juxtaposed by the equatorial region. For height, fruits were measured from apex to base. Subsequently, fruit diameter and mean height were calculated.

\section{Seed Analysis}

Fruits were divided in half by the equatorial region and seeds were manually removed, dried in the shade, with $20 \%$ water content standardization. After being separated from the fruit, seeds were classified as normal and aborted, counting normal ones. Seeds were treated with Captan 500 PM fungicide at dose of $2 \mathrm{~g} \mathrm{~L}^{-1}$, separated into five batches, with approximately 600 seeds each and stored for 12 months in high density polyethylene bags (HDPE) and placed in cold chamber with controlled temperature and relative humidity (RH) ( $5^{\circ} \mathrm{C} \pm 2 ; 85 \% \pm 5 \mathrm{RH}$ ). Water content and physiological quality of seeds were evaluated before seed storage (time 0) and 3, 6, 9 and 12 months after.

\section{Seed water content}

Water content was measured by the greenhouse method (Brasil, 2009) at $105 \pm 3^{\circ} \mathrm{C}$ for a period of 24 hours, with two subsamples per replicate. The water content was calculated by applying the following equation

$$
T A(\%)=\frac{M i-M f}{M i-T} \times 100 \text { (adapted): }
$$

where:

$\mathrm{TA}=$ water content; $\mathrm{Mi}=$ initial seed mass; $\mathrm{Mf}=$ final seed mass and; $T=$ mass of container $(T)$.

\section{Germination Test}

Germitest paper $(28 \times 38 \mathrm{~cm})$ moistened with substrate with water volume equivalent to 2.5 times the dry substrate mass was used (Brasil, 2009). Four 50-seed rolls were installed in BOD (Biological Oxygen Demand) chamber at $27^{\circ} \mathrm{C}$ with photoperiod of $12 / 12$ hours of light/ dark. Evaluations were performed 30 days after sowing, obtaining the percentage of normal seedlings.

\section{Greenhouse Emergence}

Seeds were individually placed in tubes with substrate based on pine bark in $1.0 \mathrm{~cm}$ deep furrows. The substrate was moistened whenever necessary and the final seedling evaluation was performed until emergence stabilization (60 days after test installation), considering emerged, seedlings with $1.0 \mathrm{~cm}$ shoots.

\section{Data analysis}

Fruits

Trials were installed in a completely randomized design with four replicates. Data were submitted to analysis of variance and means were compared by the Scott Knott test at 5\% significance using Assistat 7.7 software (Silva \& Azevedo, 2016).

Seeds

Trials were installed in a completely randomized 
design in a $7 \times 5$ factorial scheme (seven rootstock varieties and five storage periods: $0,3,6,9$ and 12 months), with four replicates. Data were submitted to analysis of variance, $5 \%$ Scott Knott test and regression using the SISVAR and SAS statistical software (Statistical Analysis System).

\section{Results and Discussion}

The average fruit mass ranged from 21.6 to 59.7 9 , and Poncirus trifoliata $(32.1 \mathrm{~g})$ and Sunki mandarin $(21.6 \mathrm{~g})$ fruits presented values lower than all citrandarins evaluated (Table 1). The difference in mass between species is due to the intrinsic characteristics specific of rootstock varieties.

Sunki mandarin presented the lowest diameter and mean height values, 3.8 and $3.1 \mathrm{~cm}$, respectively, compared to Poncirus trifoliata and citrandarins (Table 1). Guerra et al. (2012) evaluated the average height of Poncirus trifoliata fruits and observed value of $4.7 \mathrm{~cm}$, close to that obtained in the present study $(4.3 \mathrm{~cm})$. Schinor et al. (2015) studied 19 citrandarin genotypes

Table 1. Fruit mass, diameter and height and number of Poncirus trifoliata, Sunki mandarin and citrandarin seeds (Cordeirópolis, São Paulo State, Brazil, 2015/2016).

\begin{tabular}{lcccc}
\hline Rootstock & Mass $\mathbf{( g )}$ & $\begin{array}{c}\text { Diameter } \\
\mathbf{( c m})\end{array}$ & $\begin{array}{c}\text { Height } \\
\mathbf{( c m )}\end{array}$ & Number of seeds \\
\hline Citrandarin 70 & $53.6 \mathrm{~b}$ & $4.8 \mathrm{a}$ & $4.6 \mathrm{a}$ & $18.1 \mathrm{~b}$ \\
Citrandarin 106 & $35.0 \mathrm{e}$ & $4.0 \mathrm{~d}$ & $3.7 \mathrm{~d}$ & $11.1 \mathrm{C}$ \\
Citrandarin 254 & $40.5 \mathrm{~d}$ & $4.1 \mathrm{~d}$ & $4.0 \mathrm{C}$ & $11.1 \mathrm{C}$ \\
Citrandarin 299 & $47.4 \mathrm{C}$ & $4.4 \mathrm{~b}$ & $4.0 \mathrm{C}$ & $12.1 \mathrm{C}$ \\
Citrandarin 310 & $59.7 \mathrm{a}$ & $4.7 \mathrm{a}$ & $4.4 \mathrm{~b}$ & $9.0 \mathrm{C}$ \\
Sunki mandarin & $21.6 \mathrm{~g}$ & $3.8 \mathrm{e}$ & $3.1 \mathrm{f}$ & $5.3 \mathrm{~d}$ \\
Poncirus trifoliata & $32.1 \mathrm{f}$ & $4.3 \mathrm{C}$ & $3.5 \mathrm{e}$ & $31.9 \mathrm{a}$ \\
\hline CV (\%) & 2.8 & 2.5 & 1.5 & 9.9 \\
\hline Averages followed by the same letter in the column do not differ (Scott Knott, 5\%).
\end{tabular}

and found average height values ranging from 3.7 to $5.0 \mathrm{~cm}$. Again, such differences are due to the intrinsic characteristics of each variety.

The mean number of Poncirus trifoliata seeds (31.9) was significantly higher than the other genotypes, except for citrandarin 70 (18.1). All citrandarins presented higher number of seeds compared to Sunki mandarin (Table 1), which low seed yield was also observed in the present work $(5,3)$. The low Sunki seed yield is reported in literature (Schinor et al., 2011), as one of the limiting factors for the adoption of this rootstock.

After 12 months of storage, Poncirus trifoliata, Sunki mandarin and citrandarins 70, 106, 254, 299 and 310 seeds showed reduction in seed water content (Figure 1). This reduction can be explained by the moisture balance inside the package or by the water vapor exchange between seeds and environment inside the plastic package, even in small quantities (Smaniotto et al., 2014). There was no significant difference among evaluated varieties. According to Chochemore (1993), the type of packaging used during storage plays an important role in maintaining seed viability and vigor; packages that allow the exchange of water vapor with atmospheric air can absorb or lose water, deteriorating seeds.

Seed germination rate of Sunki mandarin at time zero (Figure 2), was higher than all evaluated varieties, but presented the lowest germination rate, along with citrandarin 310, compared to the other varieties after 12 months. Poncirus trifoliata and citrandarins 70 and 106 seeds maintained germination rate between 70 and $90 \%$, while Sunki and citrus 254, 299 and 310 showed 50-60\% (Figure 2) at 12 months of storage.

According to Carvalho and Silva (2013), trifoliate orange seeds and its hybrids are more sensitive to storage than those of other rootstocks used in the production of citrus seedlings in Brazil and may be considered recalcitrant, i.e., desiccation intolerant with short longevity, in contrast to orthodox ones (Zucareli et al., 2009). In the present work, the maintenance of seed water content above $20 \%$ and cold chamber storage with controlled temperature and relative humidity and the use of high density polyethylene (HDPE) plastic bags, which does not allow gas exchanges, prevented seeds from losing germination rate. According to Sousa et al. (2008), impermeable packaging does not allow moisture exchange with the environment, so seeds do not balance with air humidity outside the package, maintaining initial water content.

Citrandarins, Poncirus trifoliata and Sunki mandarin seeds maintained germination rates above $50 \%$ until 12 months of storage (Figure 2), i.e., according to legislation - IN 48 (MAPA, 2013), showing that the seeds of all rootstocks could still be marketed. It should be considered that there is no need for seed storage until the last evaluated period, since citrus plants have at least one annual flowering and fruit production cycle, so after 
12 months, new seed lots would be available.

Poncirus trifoliata seeds presented emergence rate over $70 \%$ during the 12 months of storage, and citrandarins 70 and 299 presented the lowest emergence rates after storage. The emergence rate decreased in all evaluated rootstock varieties during 360 days of storage (Figure 3). Siqueira et al. (2002) reported that emergence of rootstocks in greenhouse is reduced according to their

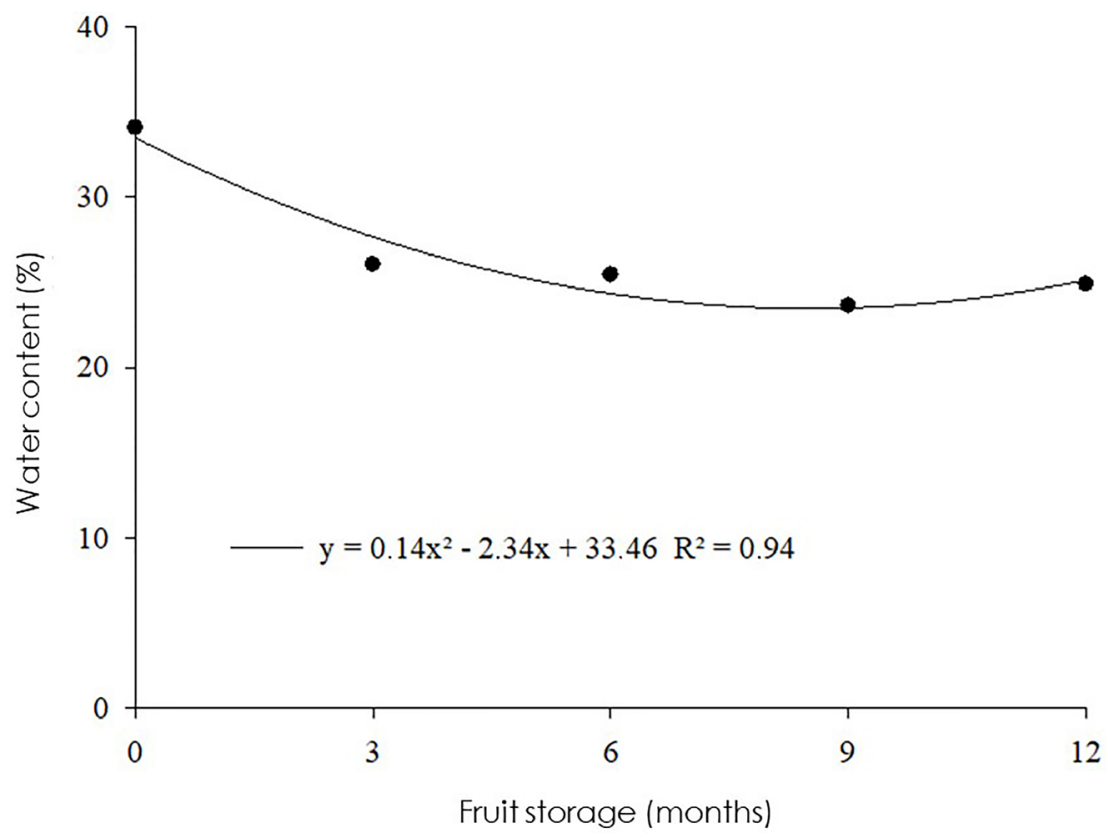

Figure 1. Water content (\%) in citrus seeds (Poncirus trifoliata, Sunki mandarin and citrandarins 70, 106, 254, 299 and 310 hybrids) during 12 months of storage (Cordeirópolis, São Paulo State, Brazil, 2015/2016)
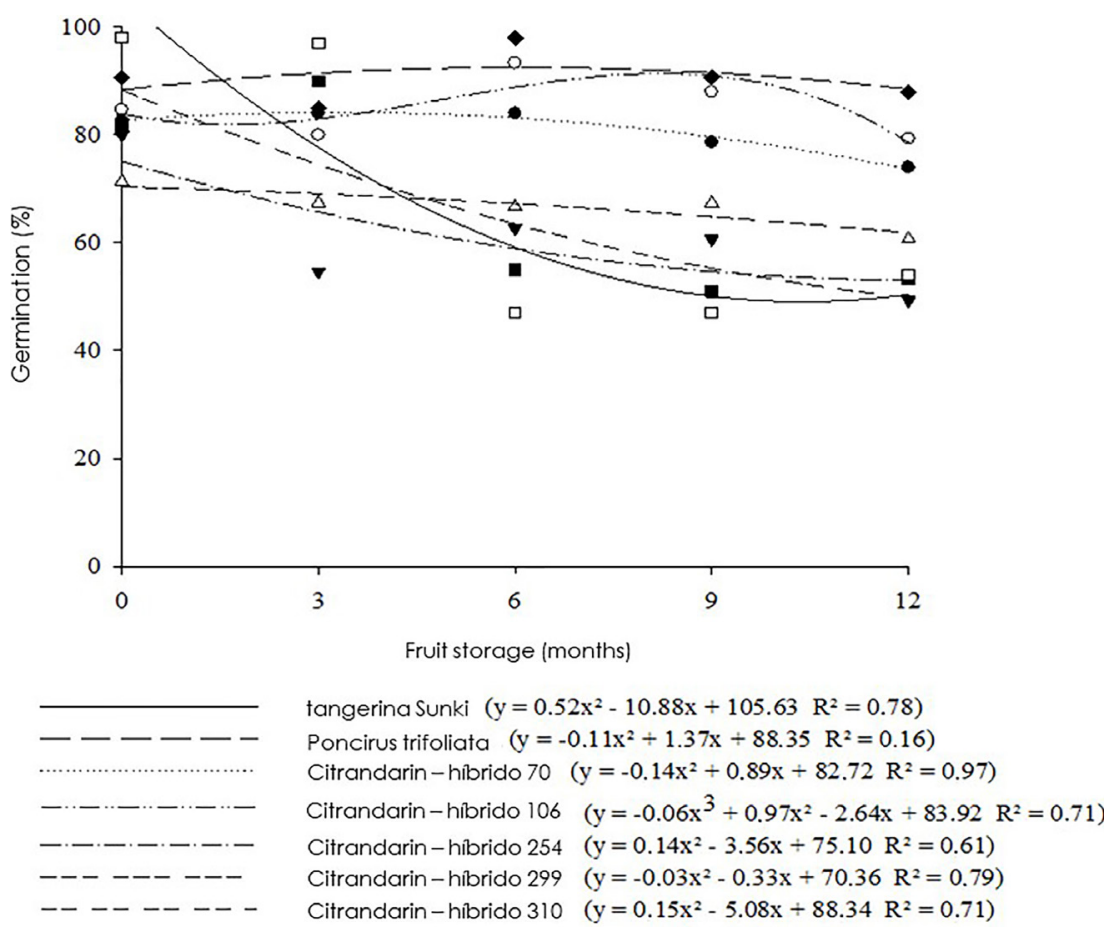

Figure 2. Germination rate (\%) of citrus seeds (Poncirus trifoliata, Sunki mandarin and citrandarins) during 12 months of storage (Cordeirópolis, SP, 2015/2016). 

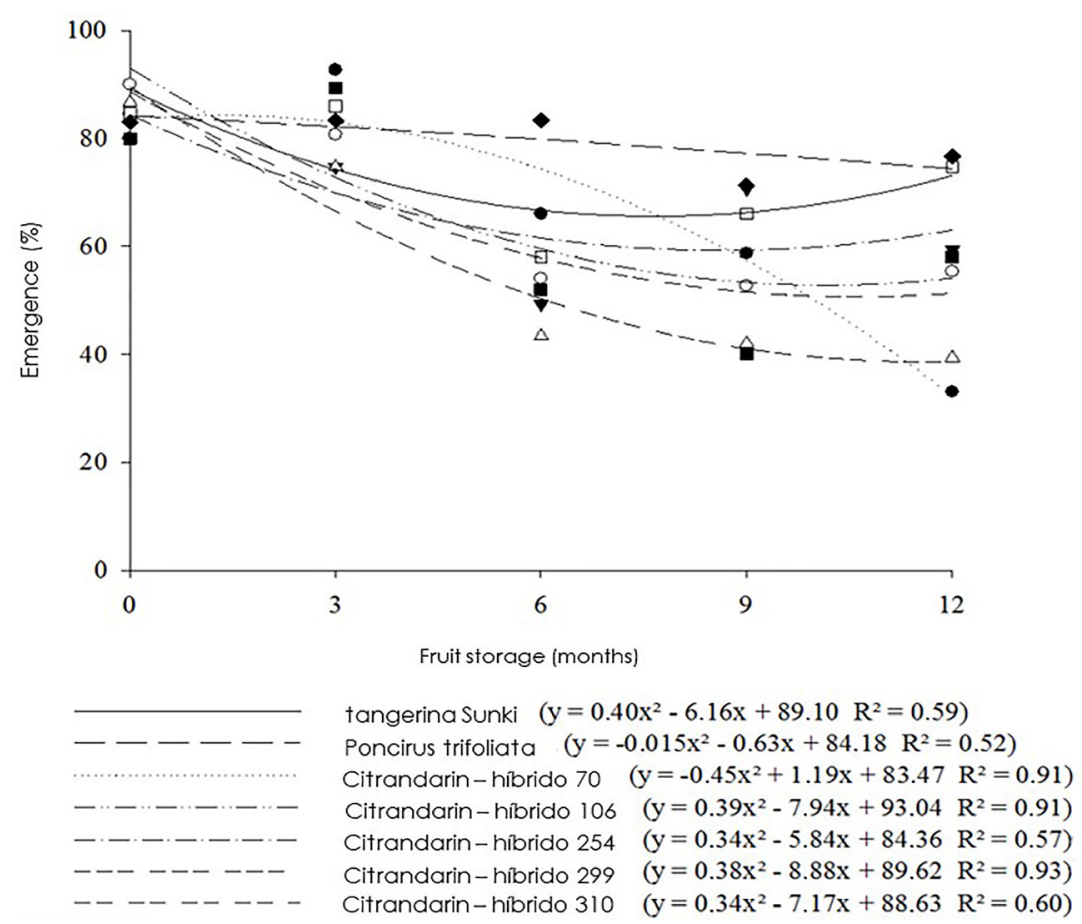

Figure 3. Emergence (\%) of citrus seeds (Poncirus trifoliata, Sunki mandarin and citrandarins) during 12 months of storage (Cordeirópolis, São Paulo State, Brazil, 2015/2016).

storage time, indicating loss of physiological quality.

\section{Conclusions}

The physiological quality of rootstock seeds (Poncirus trifoliata, Sunki mandarin and citrandarins 70 , $106,254,299$ and 310 ) decreased during storage; however, germination rate remained above $50 \%$, indicating that seeds from all rootstocks can be marketed with up to 12 months of storage. The new rootstocks tested have seeds with physiological quality compatible with their parents, in compliance with current legislation.

\section{Acknowledgments}

To FAPESP (process: 2014/16548-8) for the financial support.

\section{References}

Bassanezi, R.B., Montesino, L.H., Gasparoto, M.C.G., Bergamin Filho, A., Amorim, L. 2011 . Yield loss caused by huanglongbing in different sweet Orange cultivars in São Paulo, Brazil. European Journal of Plant Pathology 130: 577-586.

Brasil. 2009. Ministério da Agricultura, Pecuária e Abastecimento. Regras para análise de sementes. Secretaria Nacional de Defesa Agropecuária, Brasília, Brazil. 399 p.

Brito, M.E.B., Fernandes, P.D., Gheyi, H.R., Melo, A.S., Cardoso, J.A.F., Soares Filho, W.S.S. 2008. Sensibilidade de variedades e híbridos de citrange à salinidade na formação de porta-enxertos. Revista Brasileira de Ciências Agrárias 4: 343-353.
Carvalho, S.A., Silva, L.F.C. 2013. Monitoring the viability of citrus rootstocks seeds stored under refrigeration. Revista Brasileira de Fruticultura 35: 338-345.

Chochemore, M.L. 1993. Conservação de sementes de tremoço azul (Lupinus angustifolius L.) em diferentes embalagens. Revista Brasileira de Sementes 15: 227-232.

FAO. Food and Agriculture Organization of United Nations. 2015. www.faostat.fao.org<Access on 08 Oct. 2018>

Guerra, D., Schifino-Wittman, M.T., Schwarz, S.F., Souza, P.V.D., Weiler, R.L. 2012. Caracterização morfológica, determinação do número de embriões e taxa de poliembrionia em três porta-enxertos híbridos de citros. Bragantia 71: 196-201.

Jorge, M.H.A., Andrade, R.J., Costa, E. 2016. O mercado de produção de mudas de hortaliças. In: Nascimento, W.M., Clemente, F.T.V. (Org.) Produção de mudas de hortaliças. 1.ed. Embrapa, Brasília, Brazil, 308 p.

MAPA. Ministério da Agricultura Pecuária e Abastecimento. 2013. www.lex.com.br/legis_24871657_ INSTRUCAO_NORMATIVA_N_48_DE_24_DE_SETEMBRO_DE_2013.aspx<Access on 08 Oct. 2018>

Schinor, E.H., Cristofani-Yaly, M., Bastianel, M., Machado, M.A. 2013. Sunki Mandarin vs. Poncirus trifoliata Hybrids as Rootstocks for Pera Sweet Orange. Journal of Agricultural Science 5: 190-200.

Schinor, E.H., Nascimento, A.L., Barros, V.L.N.P., Bastianel, M., Azevedo, F.A., Cristofani-Yaly, M. 2015. Fruit traits and vegetative growth of citrandarins rootstocks in the Nursery. Citrus Research \& Technology 36: 27-35. 
Schinor, E.H., Siviero, A., Cristofani-Yaly, M., Marengo, S., Pompeu Junior, J., Machado, M.A. 2011. Caracterização agronômica e molecular de acessos de Citrus sunki do banco de germoplasma de citros do Centro APTA Citros Sylvio Moreira. Citrus Research \& Technology 32: 27-37.

Silva, F.A.S., Azevedo, C.A.V. 2016. Comparison of means of agricultural experimentation data through different tests using the software Assistat. African Journal of Agricultural Research 11:3527-3531.

Siqueira, D.L., Vasconcellos, J.F.F., Dias, D.C.F.S., Pereira, W.E. 2002. Germinação de sementes de porta-enxertos de Citros após o armazenamento em ambiente refrigerado. Revista Brasileira de Fruticultura 24: 317-322.

Souza, P.A., Finger, F.L., Alves, R.E., Puiatti, M., Cecon, P.R., Menezes, J.B. 2008. Conservação pós-colheita de melão Charentais tratado com 1-MCP e armazenado sob refrigeração e atmosfera modificada. Revista Horticultura Brasileira 26: 464-470.

Smaniotto, T.A.S., Resende, O., Marçal, K.A.F., Oliveira, D.E.C., Simon, G.A. 2014. Qualidade fisiológica das sementes de soja armazenadas em diferentes condições. Revista Brasileira de Engenharia Agrícola e Ambiental 18: 446-453.

Zucareli, V., Bonjovani, M.R., Cavarianil, C., Nakagawa, J. 2009. Tolerância à dessecação e influência do tegumento na germinação de sementes de citrumelo 'swingle' (Citrus paradisi MACF x Poncirustrifoliata (L) RAF.). Revista Brasileira de Fruticultura 31: 291-295.

Zucoloto, M., Costa, M.G., Carvalho, L.M., Santos, D., Siqueira, D.L. 2011 . Estimativa da produção de sementes de porta-enxertos cítricos por meio da massa de frutos. Revista Ceres 58: 126-128.

Conflict of Interest Statement: The authors declare that the research was conducted in the absence of any commercial or financial relationships that could be construed as a potential conflict of interest.

All the contents of this journal, except where otherwise noted, is licensed under a Creative Commons Attribution License attribuition-type BY. 